\title{
GROUNDWATER FLOW SYSTEMS IN MULTIPLE KARST AQUIFERS OF CENTRAL TEXAS
}

Brian A. Smith

Barton Springs/Edwards Aquifer Conservation District, 1124 Regal Row, Austin, Texas, 78748, USA, brians@bseacd.org

Brian B. Hunt

Barton Springs/Edwards Aquifer Conservation District, 1124 Regal Row, Austin, Texas, 78748, USA, brianh@bseacd.org

Douglas A. Wierman

Blue Creek Consulting, LLC, 400 Blue Creek Drive, Dripping Springs, Texas, 78620, USA, dawierman@aol.com

Marcus O. Gary

Edwards Aquifer Authority, 1615 N. St. Mary’s Street, San Antonio, Texas, 78215, USA, mgary@edwardsaquifer.org

\section{Abstract}

Increased demand for groundwater in central Hays County is prompting studies to evaluate the availability of groundwater in the Trinity Aquifers of central Texas. These aquifers, consisting mostly of limestone, dolomite, and marl, exhibit varying degrees of karstification. Near the surface, karst features such as caves and sinkholes are evident, but are widely scattered. Even at depths greater than $400 \mathrm{~m}(1,300 \mathrm{ft})$, units that are mostly limestone show some degree of karstification where dissolution along fractures has caused development of conduits. Studies are being conducted to better understand the horizontal and vertical flow components of the Trinity Aquifers. These studies involve aquifer testing, groundwater geochemistry, geologic and structural mapping, flow-loss/gain measurements in streams, hydraulic head measurements, dye tracing, and installation of multiport monitor wells. The Middle Trinity Aquifer meets the definition of a karst aquifer due to its conduit permeability within soluble rocks. However, the same aquifer has contrasting properties that are separated by the complex Tom Creek Fault Zone. The westerly Hill Country Middle Trinity Aquifer is a shallow karst aquifer system characterized by rapid conduit flow and active surface and groundwater interactions. In this area, Middle Trinity units are situated at or near the surface. To the east, the Balcones Fault Zone Middle Trinity Aquifer is a deeply confined karst aquifer system with more limited conduit development, slower groundwater flow, and no direct surface-groundwater interactions. In this area, Middle Trinity units are encountered at depths of $150 \mathrm{~m}(500 \mathrm{ft})$ or greater. The results of this study will influence future hydrogeologic and resource evaluations and modeling of the Middle Trinity Aquifer.

\section{Introduction}

With limited surface water, central Texas is fortunate to have the Edwards and Middle Trinity karst aquifer systems that provide a variety of groundwater resources. The karstic Edwards Aquifer has been recognized for decades as a vital groundwater resource, and thus many studies have been published from Hill and Vaugh (1898) to recent (Hauwert and Sharp, 2014) that characterize the nature of the aquifer and its groundwater flow system. However, few studies have focused on the karstic nature and groundwater flow system of the deeper part of the Middle Trinity Aquifer.

The Middle Trinity Aquifer of central Texas has been used as a source of water for many years, and water discharging from springs provides base flow to streams in the area. Base flows in streams that are fed by the Middle Trinity Aquifer provide recharge to the downgradient, karstic Edwards Aquifer. Rapid population growth in recent years has significantly increased the demand for groundwater. A combination of high rates of pumping and severe drought may cause undesired results such as water-supply wells going dry, worsening of water quality, and diminishment or cessation of flow from springs. Studies are being conducted to better understand the aquifers of central Texas so that proper management of these aquifers will allow for sufficient groundwater of good quality to be available for human and ecological purposes. 
The study area traverses two major physiographic provinces in central Texas: the eastern edge of the Edwards Plateau (also known as the Hill Country) and the western edge of the Gulf Coastal Plains (also known as the Blackland Prairies) defined by the prominent Balcones Escarpment-the result of the Balcones Fault Zone (BFZ). These provinces are underlain by Cretaceous strata of the region and various geologic structures (Hill and Vaughn, 1898).

The political boundaries of the study area includes the middle and western third of Hays County (Figure 1), with the focus of study on the area between the western corner of Hays County, where the Blanco River enters the county from the west, and the multiport monitor well (Hays MP) about $9 \mathrm{~km}$ (5.8 mi) northeast of the village of Wimberley.

The Middle Trinity Aquifer has recently been described as having two interconnected aquifer zones related to its physiographic and structural setting, degree of karstification, and depth beneath the surface (Hunt et al., 2017). The two aquifer zones are defined as: (1) the Hill Country Middle Trinity Aquifer (to the west), and (2) Balcones Fault Zone (BFZ) Middle Trinity Aquifer (to the east). This paper summarizes data that characterizes these two contrasting karst aquifer zones of the Middle Trinity Aquifer and develops the concept of groundwater flow between and within these two zones.

\section{Methods}

The overall study described in this paper synthesizes a number of other studies that include aquifer testing, groundwater geochemistry, geologic and structural mapping, flow-loss/gain measurements in streams, hydraulic head measurements, and installation of multiport monitor wells. Specific findings of those studies are described below.

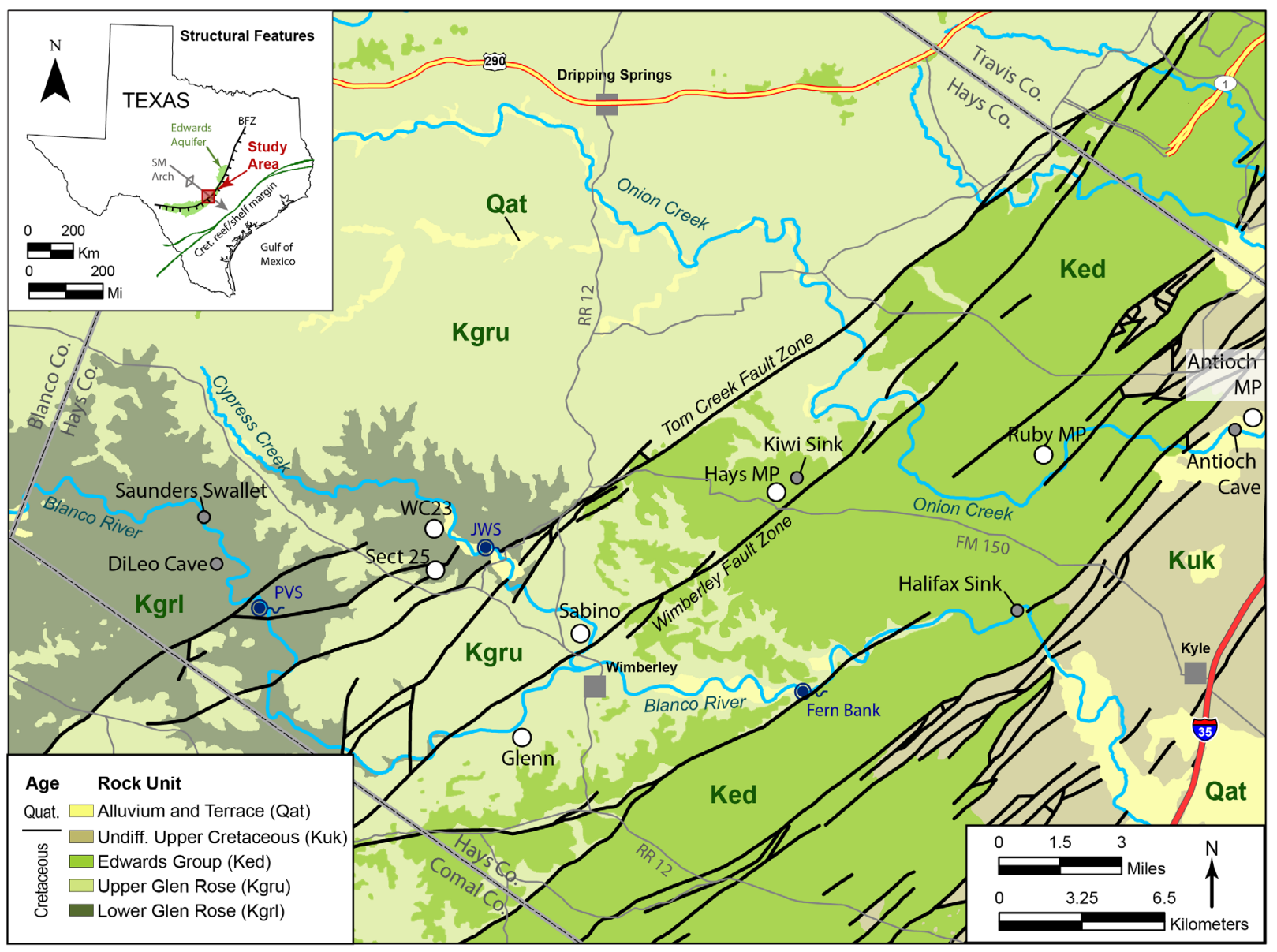

Figure 1. Simplified geologic map of the study area with key geographic and point feature locations referenced in the paper. Geologic Atlas of Texas digital basemap geology from (Stoeser et al., 2005). Inset map shows regional structures (after Ewing, 1991). SM Arch=San Marcos Arch, BFZ=Balcones Fault Zone. Detailed stratigraphic column is shown in Figure 2. 


\section{Hydrogeologic Setting Geology}

The rocks on the surface and subsurface across the study area are made up almost entirely of Cretaceous carbonate units. Figure 1 is a location and geologic map showing the general distribution of the geologic units and faults in the study area.

The eastern portion of the study area contains the Edwards Group. Stratigraphically beneath the Edwards Group is the Trinity Group that is exposed in the western portion of the study area. Figure 2 shows the litho- and hydrostratigraphy that is representative of much of Hays County.

In the western side of the study area, the outcrops are dominated by the Lower Glen Rose within the river valleys, with the Upper Glen Rose making up the hilltops. There are limited exposures of the Hensel Formation and the underlying Cow Creek Limestone along the Blanco River near Saunders Swallet (Figure 1).

The Upper Glen Rose Member is $108 \mathrm{~m}$ (355 ft) thick in the upper reaches of the Onion Creek watershed and thickens to about $137 \mathrm{~m}(450 \mathrm{ft})$ in the eastern portion of the study area. In outcrop, the Upper Glen Rose is subdivided into eight informal lithologic units, which correlate to the classic work of Stricklin et al. (1971). These units generally consist of stacked and alternating limestones, dolomites, mudstones, and marls.

The Lower Glen Rose, about $250 \mathrm{ft}$ thick, is characterized by fossiliferous limestone units with well-developed rudistid reef mounds and biostromes often found near the top and base of the unit. The shaley, dolomitic

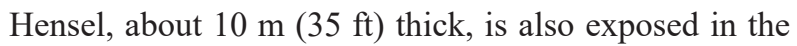
incised river valleys and locally provides semi-confining aquifer properties. The Cow Creek is about $23 \mathrm{~m} \mathrm{(75} \mathrm{ft)}$ thick. The upper portion of the Cow Creek, is a crossbedded grainstone unit that is often limestone, but can also be dolomite. The lower portion of the Cow Creek becomes more dolomitic and silty with depth grading into the underlying Hammett Shale.

\section{Structures}

Structure is an important control on the location of recharge, flow paths, and spring discharge locations in carbonate aquifers (Sasowsky, 1999). The inset map in Figure 1 illustrates the complex intersection of regional structures in the study area that influenced Cretaceous

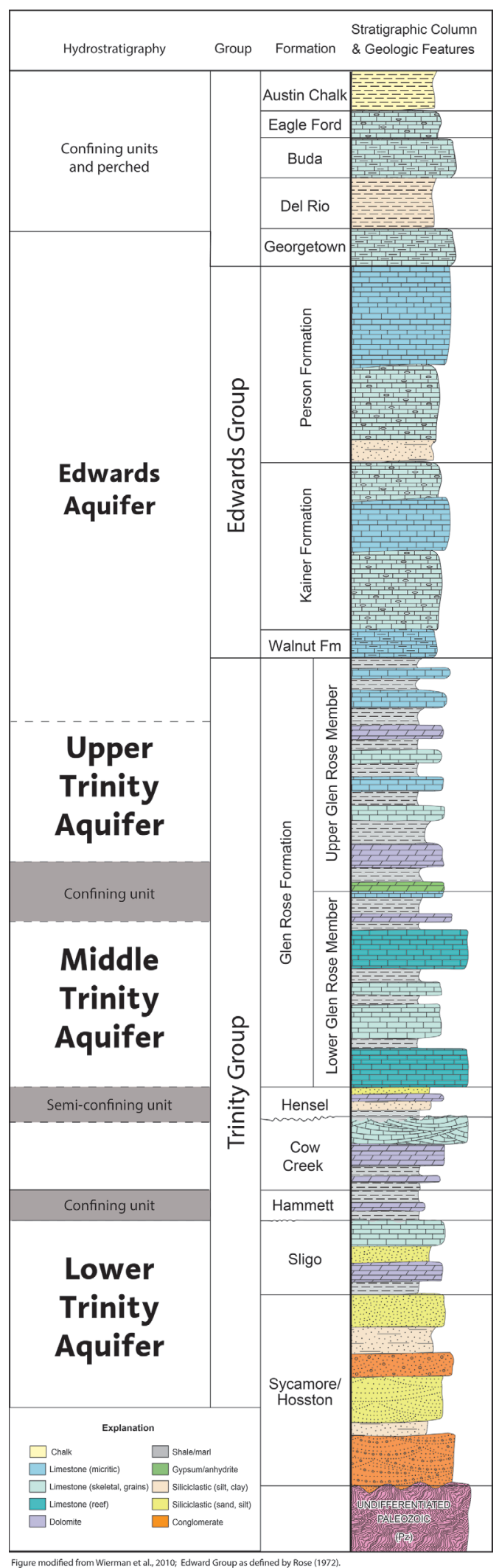

Figure 2. Stratigraphy and hydrogeology of the study area. The focus of this study is on the Upper and Middle Trinity Aquifers. 
deposition and subsequent structures, such as the Miocene Balcones Fault Zone (BFZ). The BFZ is the most significant structural feature, which covers the southeastern portion of the study area and produces the prominent physiographic feature known as the Balcones Escarpment in central Texas. The BFZ is a fault system consisting of numerous normal faults with hanging walls generally down toward the Gulf of Mexico and with displacements ranging up to $245 \mathrm{~m}$ (800 ft). Faults are generally steeply dipping (45-85 degrees) to the southeast and strike to the northeast. The faults are described as "en echelon," which indicates that they are closely spaced, overlapping and subparallel. The BFZ is characterized by structures including horsts, grabens, anticlines, monoclines, and relay ramps (Grimshaw and Woodruff 1986; Collins, 1995; Collins and Hovorka 1997; Collins, 2004; Ferrill et al. 2004; Hunt et al., 2015).
Figure 3 is a structure contour of the top of the Cow Creek Limestone. The figure illustrates the strong structural style influence of the BFZ on the Cow Creek moving from west to east into the BFZ. Within the BFZ significant deformation occurs due to the transfer of displacement from the Tom Creek/Mount Bonnell fault to the San Marcos fault to the southeast. The deformed geologic units form a large structural feature identified as a relay ramp, or transfer structure (Grimshaw and Woodruff, 1986; Collins and Hovorka 1997; Hunt et al., 2015). The influence of relay ramps on groundwater flow is such that where the amount of throw along a fault is significant, flow of groundwater may be impeded. Where the amount of throw in minimal, or non-existent, the flow of groundwater will be unimpeded.

The Tom Creek fault is of particular importance to this study (Figures 1 and 3). The fault extends northeast-

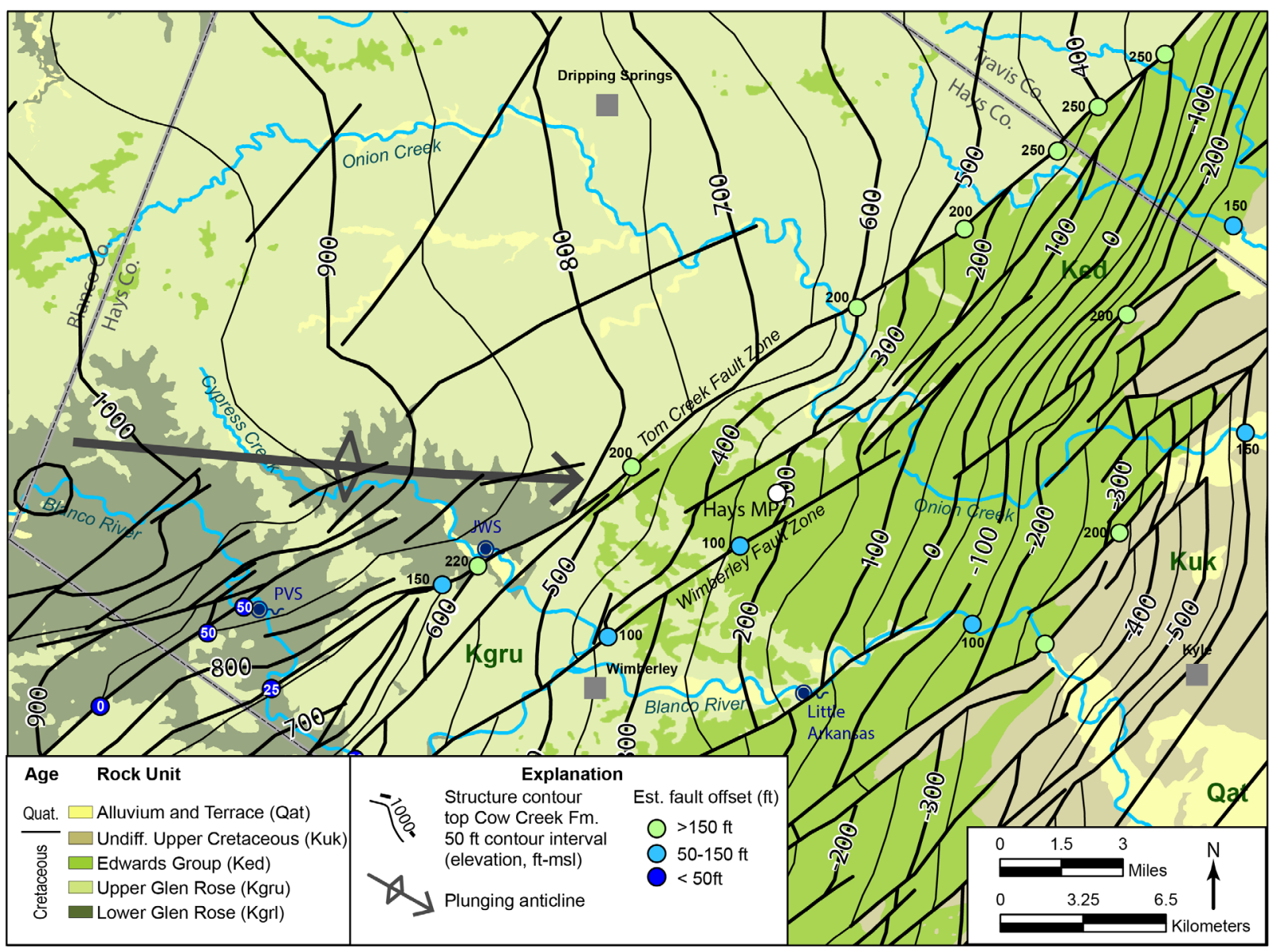

Figure 3. Structure and geologic map of the study area. Structure contours on the top of the Cow Creek show dip to the ENE to the north of the anticline. South of the anticline the structural style consists of highly faulted blocks between the Tom Creek and San Marcos Faults forming a relay ramp structure. Contours were hand drawn using more than 300 control points (most of which are geophysical logs) and faults modified from the Geologic Atlas of Texas (Al Broun, unpublished data). 
southwest through Wimberley with throws of as much as $76 \mathrm{~m}(250 \mathrm{ft})$ to the east where the fault crosses into Travis County. Yet, about $3 \mathrm{~km}$ (2 mi) west of Wimberley, the Tom Creek fault has throws of about $15 \mathrm{~m}(50 \mathrm{ft})$, and close to zero meters another $3 \mathrm{~km}(2 \mathrm{mi})$ to the southwest. Northwest of Wimberley, a broad, eastward plunging anticline is delineated by structural contours drawn on the top of the Cow Creek Limestone. The nature of the varying offsets along the Tom Creek fault is similar to the relay ramp structures discussed above. Another significant structure is a horst block, which has allowed for uplift and exposure of the Cow Creek Limestone at the surface within the bed of the Blanco River (Figure 1, area around Saunders Swallet).

\section{Hydrogeology}

Recent studies have refined the hydrostratigraphy of the study area (Smith and Hunt, 2010; Smith et al., 2013; Wong et al., 2014). The principal conclusions that were drawn from these studies are outlined below and summarized in the hydrostratigraphic column in Figure 2.

The Trinity Group geologic units have historically been divided into three aquifers: the Upper Trinity (Upper Glen Rose Member), the Middle Trinity (Lower Glen Rose Member, Hensel, Cow Creek), and the Lower Trinity (Sligo and Hosston Formations) (DeCook, 1963; Ashworth, 1983; Barker et al., 1994; Barker and Ardis, 1996; Mace et al., 2000; Wierman et al., 2010). The Hammett Shale is a confining unit that separates the Middle and Lower Trinity Aquifers. Figure 2 demonstrates that the hydrogeologic units (or aquifers) do not necessarily correlate to lithostratigraphic units (Smith et al., 2013; Wong et al., 2014).

In the eastern part of the study area, the upper $45 \mathrm{~m}$ $(150 \mathrm{ft})$ of the Upper Glen Rose Limestone are hydraulically connected to the overlying Edwards units. The lower $90 \mathrm{~m}$ (300 ft) of the Upper Glen Rose, and farther east, the upper portion of the Lower Glen Rose is best characterized as an aquitard. The units have intervals of evaporite minerals that occlude the porosity and permeability (Figure 4). Some of these intervals consist largely of interlocking evaporite nodules. While some of these intervals have evaporite nodules separated by a dolomitic matrix. These units are characterized as having low permeability and porosity, poor water quality, and water levels that change very little. Where these units are situated close to the surface, the evaporites have been largely removed by dissolution from infiltration by meteoric water and replaced by calcite (Figure 5).

Based on a regional compilation of aquifer test data, average transmissivities of the Middle Trinity Aquifer $50 \mathrm{~m}^{2} / \mathrm{d}\left(535 \mathrm{ft}^{2} / \mathrm{d}\right)$ are lower than the Edward Aquifer $890 \mathrm{~m}^{2} / \mathrm{d}\left(9,600 \mathrm{ft}^{2} / \mathrm{d}\right)$. However, hydraulic conductivity of the Middle Trinity Aquifer is comparable to the Edwards Aquifer with average values of $3.4 \mathrm{~m} / \mathrm{d}(11 \mathrm{ft} / \mathrm{d})$ and $8.5 \mathrm{~m} / \mathrm{d}(28 \mathrm{ft} / \mathrm{d})$, respectively (Hunt et al., 2010). The Cow Creek is the most prolific water-producing hydrologic unit in the Middle Trinity.

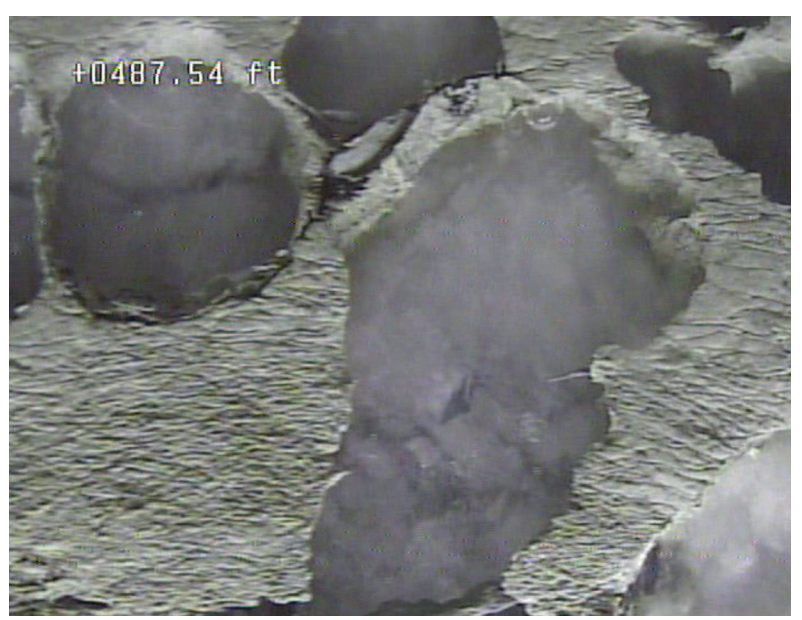

Figure 4. Photograph of a side view of a borehole showing evaporite (gypsum) nodules developed in the Upper Glen Rose. The photograph was taken at a depth of 150 m (490 ft) in the Hays MP well (Figure 1).

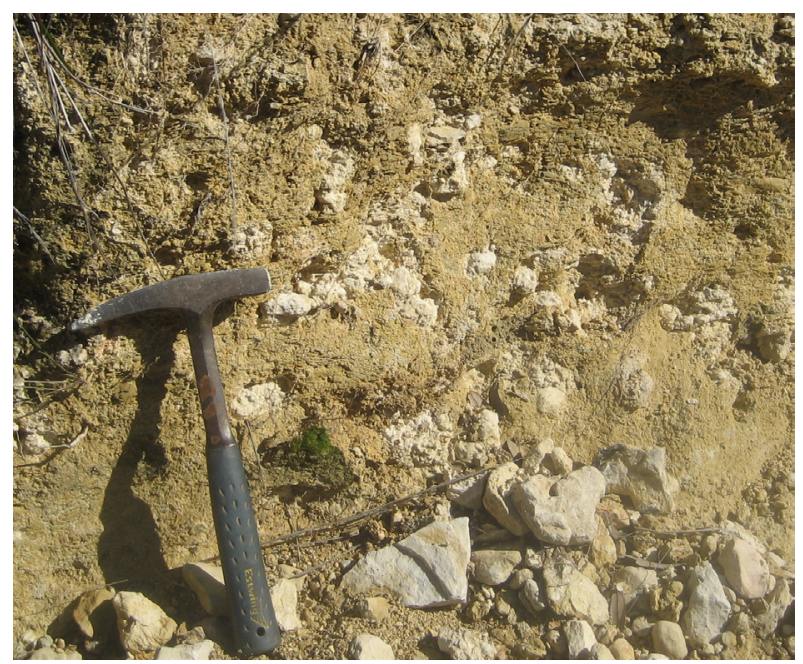

Figure 5. Photograph of an outcrop of relict evaporite nodules within the lower-most Upper Glen Rose. 
The Hensel is a water-bearing unit west of the study area, and is thought to be conducive to recharge directly from the surface or through overlying units. In the study area, the Hensel is a silty dolomite and behaves as a semiconfining unit on top of the Cow Creek, and is locally breached with fractures and solution features.

The Lower Glen Rose is also an important hydrologic unit within the Middle Trinity Aquifer with the best production occurring within the lower rudist reef facies, which has vertical and lateral heterogeneity. The Lower Glen Rose is also highly karstic with numerous mapped caves in the western portion of the study area (Delio Cave, Figure 1). Over much of the study area, particularly in the deeper sections, portions of the Lower Glen Rose and the Hensel provide confinement to the underlying Cow Creek Limestone.

\section{Karst}

The Middle Trinity Aquifer is a karstic and fractured aquifer (Wierman et al., 2010) with karst features found in the very shallow subsurface and at depths of more than $300 \mathrm{~m}(1,300 \mathrm{ft})$. In the western portion of the study area, numerous caves, swallets, and springs are found within the Lower Glen Rose and Cow Creek Limestone (Figure 1). One example of a recharge feature in the Cow Creek Limestone (Middle Trinity) is Saunders Swallet (Figures 1 and 6), which takes in water flowing in the Blanco River. The Cow Creek also provides substantial flow to the Blanco River with discharges from Jacob's Well Spring (JWS) and Pleasant Valley Springs (PVS), which are both artesian springs (Figure 1). JWS is a significant karst conduit in which scuba divers have mapped more than $3.5 \mathrm{~km}$ (2.2 mi) of passage in the Cow Creek Limestone (Figure 7). Prior to discharging from JWS, groundwater flows upward through the Hensel and out to the surface through an opening in the Lower Glen Rose. Although the Hensel is confining in the vicinity of Jacob's Well and Pleasant Springs, it is clearly permeable in some locations in the recharge zone to the west since the Cow Creek is recharged from an area much larger than the small window of exposed Cow Creek in the Blanco River (Hunt et al., 2017).

In the subsurface, and east of the recharge zone, there are numerous observations of voids that result from karst processes. Those features have been observed from driller, geophysical, and camera logs. Solutionally enlarged fractures have been observed in the Cow Creek

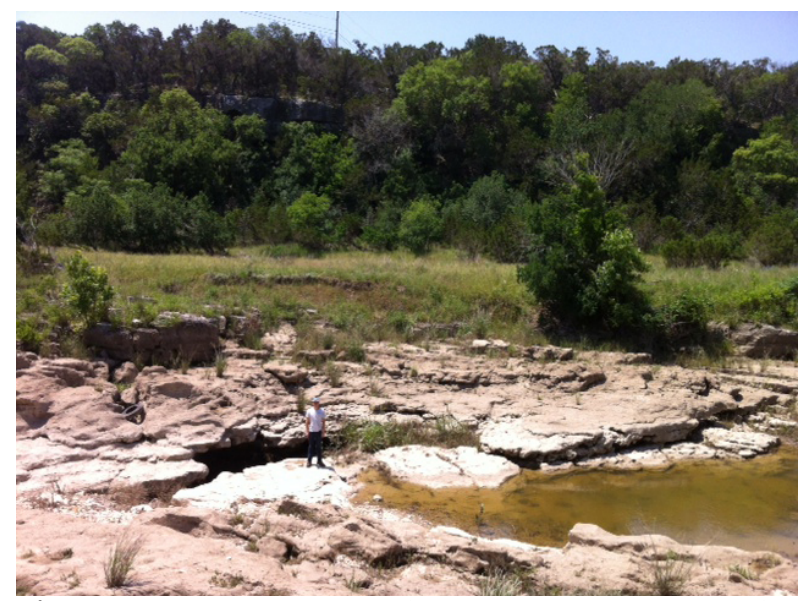

Figure 6. Photograph of Saunders Swallet. This recharge features is located in the Blanco River and developed within the Cow Creek Limestone. Water was flowing into the swallet, where the person is standing, when the photograph was taken in 2013.

in the Antioch multiport well (Antioch MP; Figure 1) just west of Buda, at depths of about $400 \mathrm{~m}(1,300 \mathrm{ft})$ (Figure 8). Despite the presence of karst features at depth, east of the major Middle Trinity springs the conduit development is not as mature and thus groundwater is not flowing as rapidly under natural conditions. The karst features at depth, however, do allow for locally very highly transmissive properties for wells. Test wells near the multiport monitor well Hays MP (Figure 1) can yield up to about 45 liters per second ( 700 gallons per minute) during pumping with reported average transmissivities of about $80 \mathrm{~m}^{2} / \mathrm{d}\left(870 \mathrm{ft}^{2} / \mathrm{d}\right.$; WRGS, 2017).

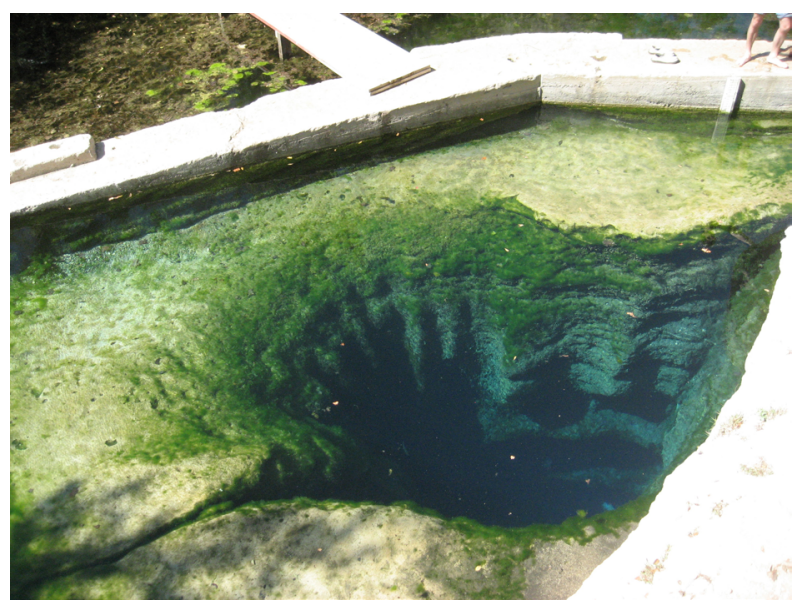

Figure 7. Photograph of Jacob's Well Spring. The spring issues from a significant karst conduit in which scuba divers have mapped more than $3.5 \mathrm{~km}$ (2 miles) of passage in the Cow Creek Limestone. Photograph taken in 2011. 


\section{Recharge}

Historically the Trinity Aquifer was not considered a karst aquifer and recharge was conceptualized to broadly absorb only 4\% of rainfall as recharge (Ashworth, 1983). Conversely, recharge to the karstic Edwards Aquifer was known to be dominated by losing streams (Slade et al., 1986 ) with recharge of up to $30 \%$ of rainfall, typical of many karst aquifers (Hauwert and Sharp, 2014). Figure 1 shows the locations of some karst features within streams in the Edwards Aquifer recharge zone (Antioch Cave, Halifax Sink).

Recent studies (Smith et al., 2015; Hunt et al., 2017) indicate significant recharge to the Middle Trinity occurs from losing streams, such as the Blanco River, Cypress Creek, and Onion Creek (Figures 6 and 9). The losing reaches of the Blanco River and Cypress Creek sustain PVS and JWS, respectively. Any water in the Cow Creek that does not exit the aquifer at the springs probably provides flow to the deeper part of the Middle Trinity Aquifer. As discussed below, chemical analyses of groundwater from deep wells to the east indicate that the water in some of the wells has low conductivity and total dissolved solids. This suggests that there is a pathway for water from the shallow system to move deeper into the subsurface.

Another source of recharge to the Middle Trinity is vertical leakage from the overlying Upper Glen Rose (Jones et al., 2011). Recharge to the Balcones Fault Zone Middle Trinity Aquifer in the vicinity of the Hays MP well is primarily from lateral flows from the

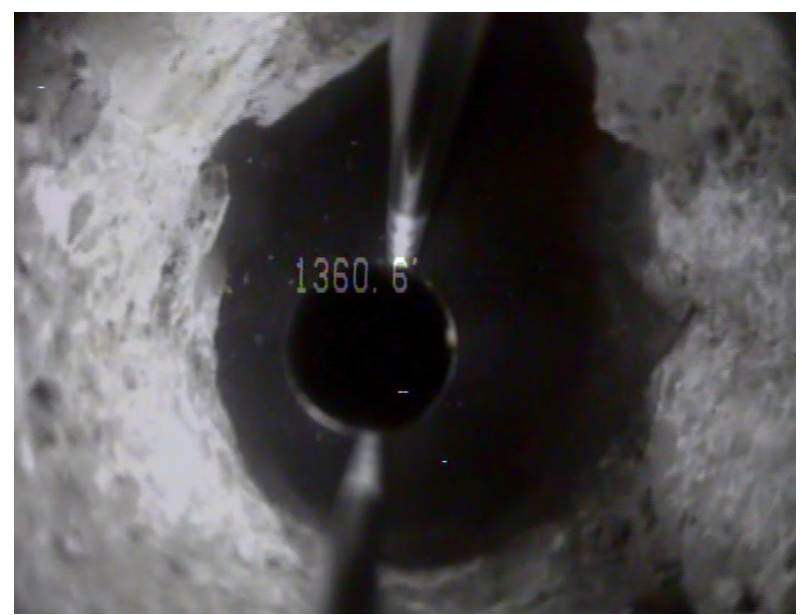

Figure 8. Photograph of a solution-enlarged fracture and void within the Cow Creek Limestone in a borehole at a depth of $400 \mathrm{~m}$ $(1,360 \mathrm{ft})$. updip recharge area to the west (Smith et al., 2015; Wong et al., 2014). However, there is some indication of a hydrologic connection (vertical leakage) from the Upper Glen Rose into the Middle Trinity either due to significant head gradients from recharge in the Upper Glen Rose or drawdown from pumping from the Middle Trinity Aquifer (BSEACD, 2017). Much of the recharge to the Upper Trinity Aquifer is from direct precipitation and infiltration in areas where the Upper Trinity geologic units are exposed at the surface (Wierman et al., 2010). Some of this is diffuse infiltration through soils and some is through recharge features such as Kiwi Sink (Location shown in Figure 1). The entrance to Kiwi Sink is in a thin veneer of the base of the Edwards Group and the opening penetrates into the Upper Glen Rose. This sinkhole is within $300 \mathrm{~m}(1,000 \mathrm{ft})$ of the Hays MP multiport monitor well.

\section{Potentiometric Surface Mapping}

The network of monitor wells in the study area has expanded considerably in the past 10 years as access has been gained to many private wells, and instruments for recording water levels have been increasingly used. Figure 9 shows a regional Middle Trinity potentiometric map created during March 2009. These measurements show that regional flow of groundwater in the Middle Trinity generally follows the dip of the strata. However, flow is to the northeast and parallel to the Tom Creek/ Mount Bonnell fault zone where offsets along the fault are greater than $250 \mathrm{ft}$ and suggest a barrier to flow.

Another potentiometric map on Figure 9 is focused on an area west of Wimberley. Water-level data were collected from Middle Trinity wells in 2013 (Watson et al., 2014). Contours of this data set show a similar pattern to the 2009 data, but the greater density of data in the 2013 study shows several features, including: (1) a large potentiometric trough along Cypress Creek reflecting the highly permeable JWS conduit development, and (2) a steeper gradient of flow east of JWS near Wimberley that likely reflects a decrease in permeability, and (3) more widely spaced contours to the west of Wimberley indicating potentially higher permeability than the area to the east. Considerable offset of the Cow Creek along the Tom Creek fault provides some amount of restriction to lateral flow near Wimberley. To the west, where the amount of throw is less, or nonexistent, there is less restriction to flow through the Cow Creek due to structural influences such as relay ramps (Hunt et al., 2015). 


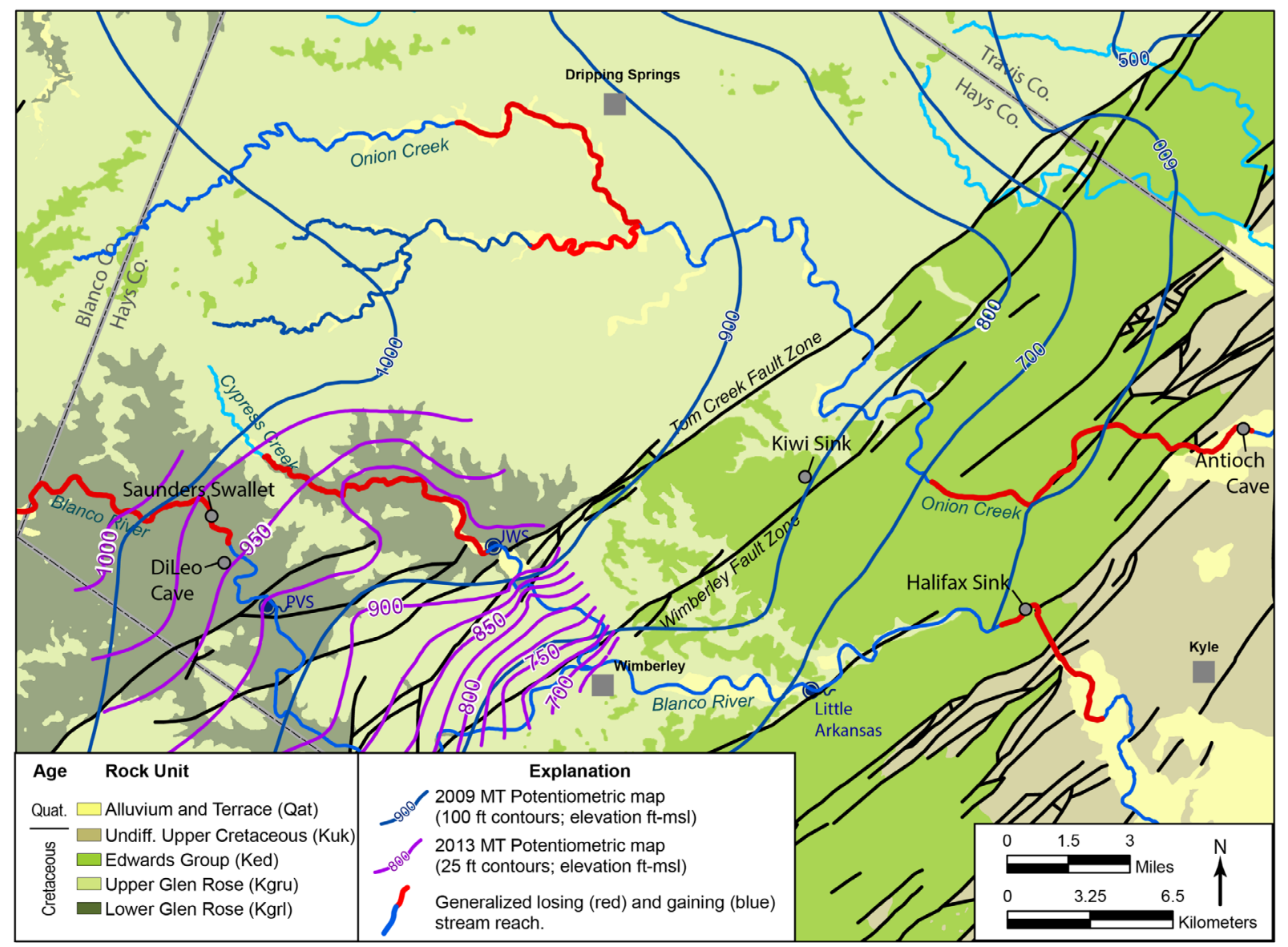

Figure 9. Regional (Hunt et al., 2010) and localized (Watson, et al., 2014) potentiometric maps of the Middle Trinity Aquifer with losing and gaining reaches of streams and karst features.

Continuous water-level measurements recorded over the past 10 years show significantly different water-level patterns between Middle Trinity wells on the upthrown side of the Tom Creek fault (WC23, HCP3, Graham) compared to Middle Trinity wells (Sabino and Glenn) on the downthrown side (Figure 10). Because of the moderating influence of JWS as it acts as a significant drain for the Middle Trinity Aquifer in this area, water levels approach a baseline during dry periods. Following major rain events, water levels in these wells spike, but quickly return to near base-flow conditions mimicking the response at JWS, thus indicating the influence of conduit (karst) flow on the upthrown side of the fault.

Middle Trinity wells on the downthrown side of the fault show as much as $45 \mathrm{~m}(150 \mathrm{ft})$ of head change between wet and dry periods with gradual rises and falls in water levels. On average, water levels on the downthrown side are about $50 \mathrm{~m}(165 \mathrm{ft})$ lower than water levels on the upthrown side of the fault. These data suggest that the Tom Creek fault zone demarks a change in the permeability structure within the Middle Trinity Aquifer, and thus may partially restrict the northwest to southeast flow of groundwater.

\section{Multiport Monitor Well}

In February 2017, a multiport monitor well (Hays MP; Figure 1) was installed in the Rolling Oaks subdivision of central Hays County, Texas. This well was installed to better understand the horizontal and vertical relationships of the various hydrologic units of the Trinity Group. Initial head and geochemical results indicate a complex stratified aquifer system. In general the data support a deep karstic aquifer within the Cow Creek and Lower Glen Rose beneath a shallow karst aquifer developed in the uppermost Upper Glen Rose. The top of the Cow Creek is at about $230 \mathrm{~m}(750 \mathrm{ft})$ below ground surface with heads $232 \mathrm{~m}$ above mean sea level $(760 \mathrm{ft}-\mathrm{msl})$ and total dissolved solids (TDS) content of $1,550 \mathrm{mg} / \mathrm{L}$. The Upper Glen Rose contains groundwater with about 


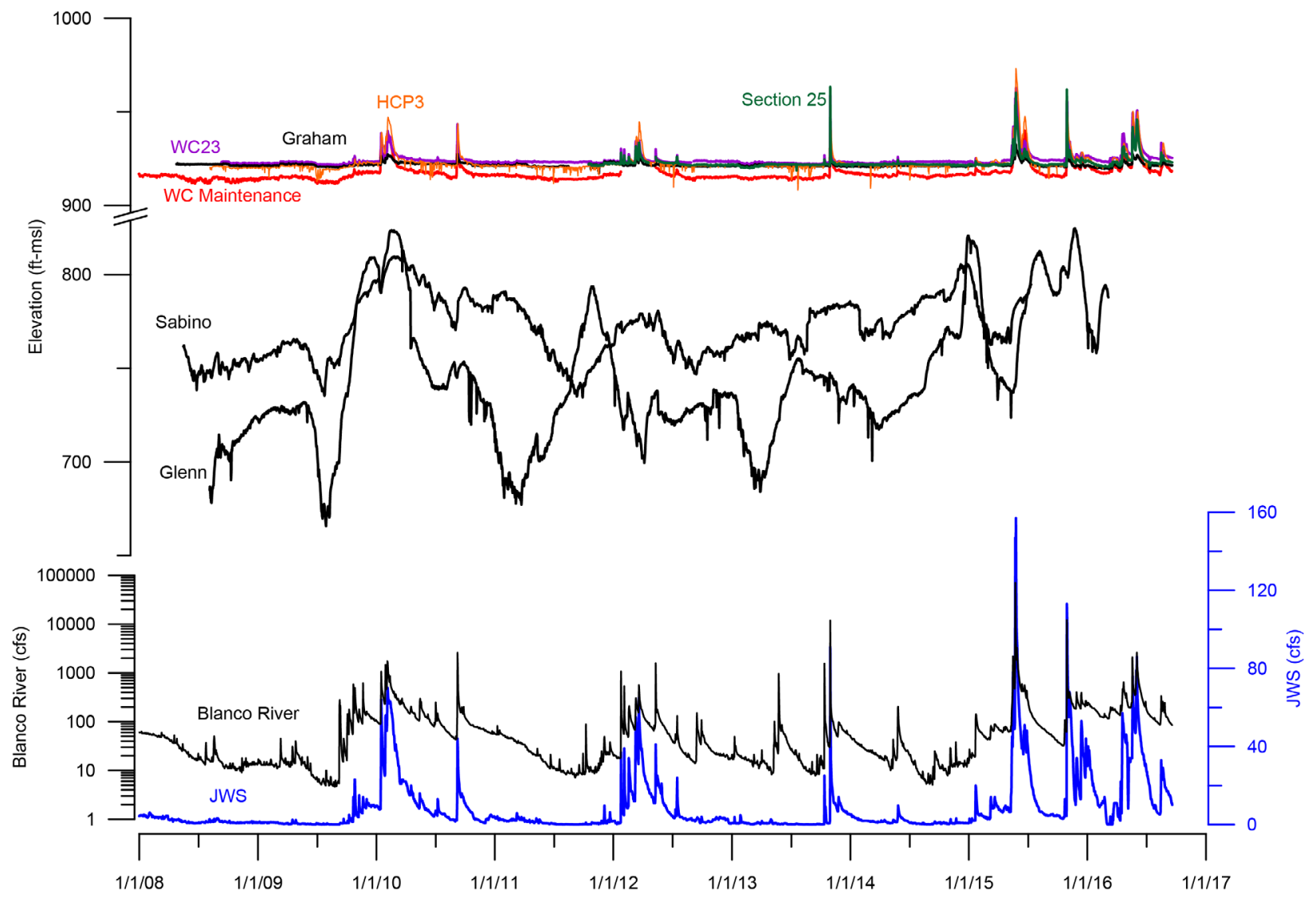

Figure 10. Hydrograph from wells, Jacob's Well Spring, and the Blanco River at Wimberley. Source data from the Hays-Trinity Groundwater Conservation District.

$600 \mathrm{mg} / \mathrm{L}$ TDS to a depth of about $100 \mathrm{~m}(330 \mathrm{ft})$ below ground surface with heads at $265 \mathrm{~m}-\mathrm{msl}(870 \mathrm{ft}-\mathrm{msl}$; BSEACD, 2017). Several intermediate zones contain gypsum and have up to $3,180 \mathrm{mg} / \mathrm{L}$ TDS, with heads between the deep and shallow aquifers. These beds appear to correspond to gypsum-bearing aquitard units in other multiport wells described in Wong et al. (2014) and found in Figure 1 (Ruby MP, Antioch MP).

\section{Geochemistry and Relative Groundwater Age}

Major ion and isotope geochemistry can provide additional information about the source, recharge, and flow paths of groundwater. Figure 11 is a contour map showing the distribution of TDS in the Middle Trinity (Hunt et al., 2017) and results of carbon-14 isotopes (14C) shown as percent modern carbon (pmC) (TWDB, 2017) in the Middle Trinity Aquifer.

The $500 \mathrm{mg} / \mathrm{L}$ contour helps to define where much of the recharge is actively occurring. The $1,000 \mathrm{mg} / \mathrm{L}$ TDS contour tends extends irregularly from the recharge areas, including to the east along a relay ramp and along the potentiometric gradient (Hunt et al., 2015 and 2017).

The spatial trends of carbon-14 and tritium values in the Middle Trinity are similar in the study area, with lower values present to the east of PVS and JWS. Samples of Middle Trinity groundwater collected from JWS and PVS $(\mathrm{n}=9)$ have relatively high average $\mathrm{pmC}(88 \%)$ and tritium $(1.7 \mathrm{TU})$ indicating the water is relatively young to modern (less than 50 yrs old). Middle Trinity well-water samples have a range of carbon-14 values spanning $0-120 \% \mathrm{pmC}$ $(\mathrm{n}=61)$ and tritium 0-2.3 TU (n=60) (TWDB, 2017). These data suggest a range of very old, greater than 10,000 years, to modern groundwater, less than 50 years old, respectively, depending on the proximity of the well to the recharge zone and influence by karst features. The good correlation of the radiogenic isotopes suggests some degree of mixing of modern water with older water, likely influenced by relatively rapid flow through karst features, but also supports the concept of much older groundwater east of the major springs and east of the Tom Creek fault. 


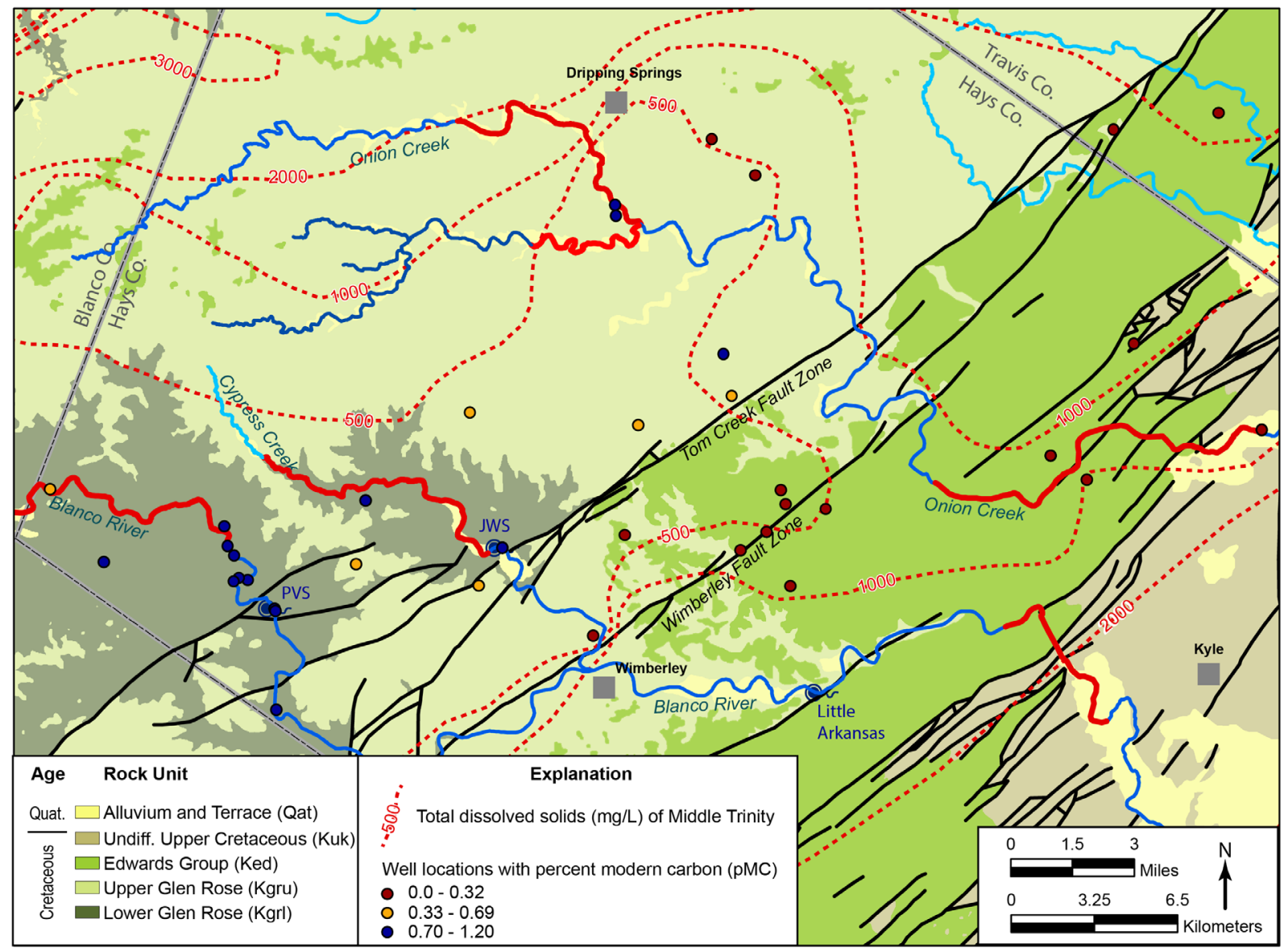

Figure 11. Total dissolved solids and carbon-14 map of the Middle Trinity Aquifer. Contours show fresh water (less than $500 \mathrm{mg} / \mathrm{ll}$ ) over the net losing portions of the Blanco River and Onion Creek. Carbon- 14 samples are also shown with the relatively young water within the recharge zone of the Hill Country Trinity Aquifer and relatively older water within the BFZ Middle Trinity Aquifer east of the recharge zone.

\section{Discussion}

Data from the studies discussed above indicate a very complex system of stacked and juxtaposed karst aquifers across much of Hays County. Figure 12 is a summary diagram and conceptual model. This study focuses on the Middle Trinity Aquifer and its lateral changes from the Hill Country into the BFZ, generally expressed by the degree of karstification of the Cow Creek and Lower Glen Rose Limestone. In the Hill Country Middle Trinity Aquifer there is a shallow, generally unconfined, well-developed karst aquifer system. In the areas to the west where the Middle Trinity units crop out, there are sinkholes, swallets, and small solution features where recharge is observed. Major recharge features conduct water from the Blanco River and tributaries into the Middle Trinity Aquifer. From these areas of recharge, some of the water flows within conduits east to discharge at PVS and JWS. With a greater average discharge, PVS probably has a similar plumbing system of conduits, but is not accessible by divers. The groundwater in this portion of the aquifer, with generally low TDS values, has a relatively young to modern age and is part of active surface-groundwater interactions.

To the east, these same units make up the BFZ Middle Trinity Aquifer and are found at depths of $245 \mathrm{~m}$ (800 ft) and greater. The aquifer is under confined conditions with fractures enlarged by dissolution. The conduit development is not as mature as the shallow system to the west, and thus groundwater is not flowing as rapidly under natural conditions. However, some high yielding deep wells have very good water quality with TDS values of less than $1,000 \mathrm{mg} / \mathrm{L}$. The closest likely recharge area is about $11 \mathrm{~km}(6.9 \mathrm{mi})$ to the west along the Blanco River. Despite the low TDS water (less than $1,000 \mathrm{mg} / \mathrm{L}$ ), the relatively old age suggests that the groundwater is on a less active pathway than in the recharge zone. 


\section{Upper Trinity Aquifer}

\section{Hill Country Middle Trinity Aquifer}

BFZ Middle Trinity Aquifer

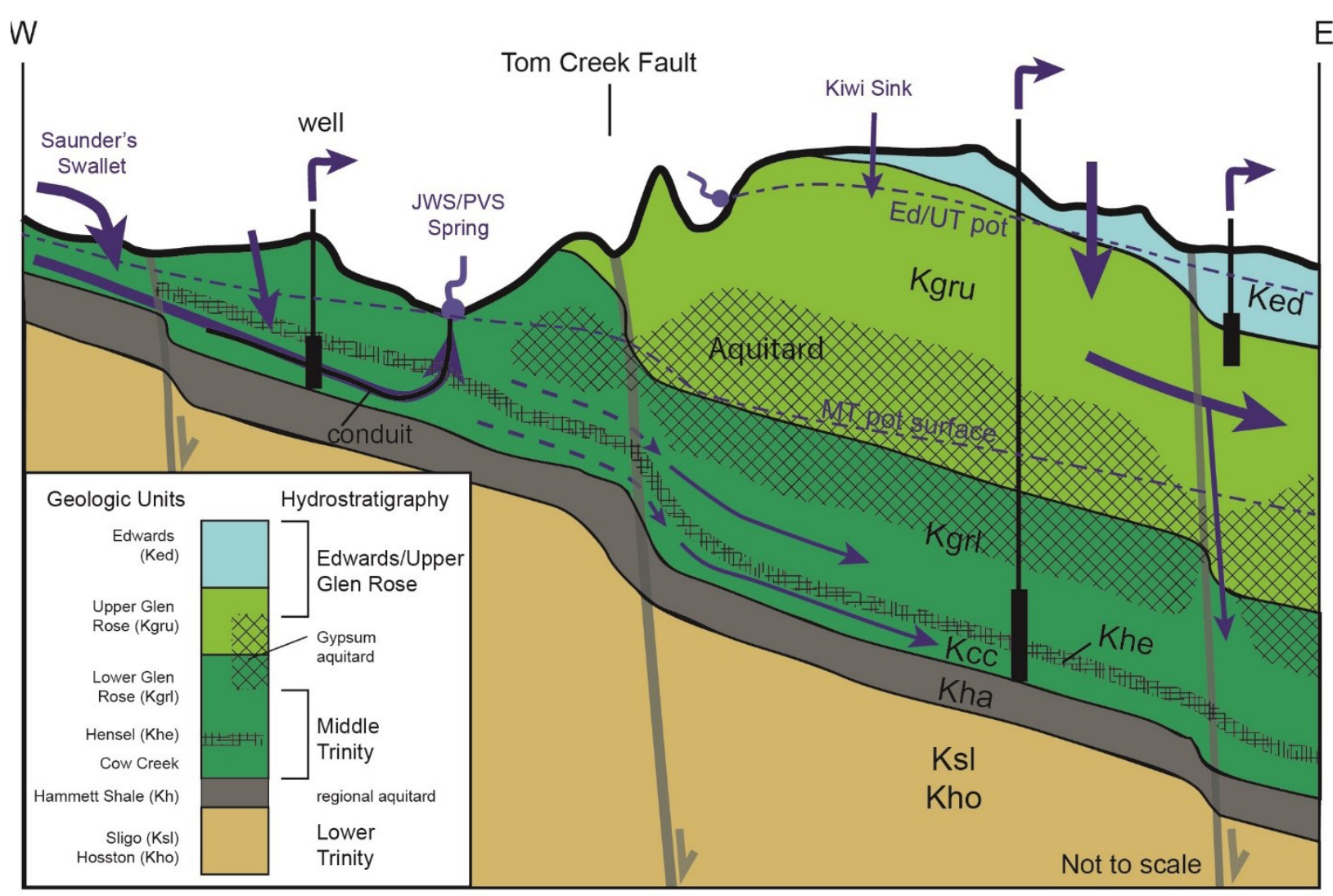

Figure 12. Schematic cross section and conceptual model.

The transition from the Hill Country Middle Trinity Aquifer into the BFZ Middle Trinity Aquifer occurs across a major fault zone (Tom Creek), with throws of up to $76 \mathrm{~m}(250 \mathrm{ft})$. Moving from northeast to southwest, the fault zone decreases in offset. In the north near Travis County the fault appears as a barrier to flow as demonstrated by the northeast direction of groundwater flow. Moving southwest into the JWS area potentiometric gradients turn to the southeast, but become much steeper indicating relatively lower permeability and likely restricted flow across the fault zone. Continuing southward toward PVS, the gradients become less steep, likely more permeable, and with flow to the east-southeast. The change in gradient is generally coincident with a relay-ramp structure that allows for continuity of the geologic units from the Hill Country Trinity Aquifer into the BFZ Trinity Aquifer.
Hydrographs and geochemistry indicate that the fault zone delineates a change in the permeability field, likely related to the degree of karst development.

Other studies have shown that in the BFZ, the uppermost Upper Glen Rose is in hydrologic communication with the overlying Edwards Group where the Edwards is saturated (Wong et al., 2014). The degree of vertical hydrogeologic connection between the Upper Trinity Aquifer and the underlying BFZ Middle Trinity aquifer is poorly understood. Recent aquifer test data indicate a local hydrologic connection depending upon climatic conditions or drawdown from pumping.

\section{Conclusions}

The Middle Trinity Aquifer meets the definition of a karst aquifer due to its conduit permeability within 
soluble rocks. However, the same aquifer has contrasting properties that are separated by the complex Tom Creek Fault Zone. The westerly Hill Country Middle Trinity Aquifer is a shallow karst aquifer system influenced by rapid conduit flow and characterized by active surface and groundwater interactions. The Balcones Fault Zone Middle Trinity Aquifer, to the east, is a deeply confined karst aquifer system with more limited conduit development, with no direct surface-groundwater interactions, and slower groundwater flow.

The implications of this study will influence future hydrogeologic evaluations and modeling. Evaluations include the potential for impacts to existing domesticsupply wells by large-scale pumping of wells completed in the Balcones Fault Zone Middle Trinity Aquifer. Groundwater management districts in Texas are responsible for the protection of aquifers and the users of those aquifers. A better understanding of these complex systems will allow for policy decisions that will minimize the potential for unreasonable impacts from groundwater pumping on wells and springs.

\section{References}

Ashworth JB. 1983. Ground-water availability of the Lower Cretaceous formations in the Hill Country of south-central Texas. Texas Department of Water Resources Report 273. 173 p.

Barker R, Bush P, Baker E. 1994. Geologic history and hydrogeologic setting of the Edwards-Trinity aquifer system, west-central Texas. US Geological Survey Water-Resources Investigations Report 94-4039. 49 p.

Barker RA, Ardis AF. 1996. Hydrogeologic framework of the Edwards-Trinity aquifer system, westcentral Texas, US Geological Survey Professional Paper 1421-B.

BSEACD (Barton Springs/Edwards Aquifer Conservation District). 2017. Hydrogeologic setting and data evaluation: 2016 Electro Purification aquifer test, Cow Creek well field: Hays County, Texas. Technical Memo 2017-1010. 39 p. + Appendices.

Broun AS. 2010. Isopach and structure maps. In: Wierman D, Broun A, and Hunt B, editors. Hydrogeologic atlas of the Hill Country Trinity Aquifer, Blanco, Hays, and Travis Counties, Central Texas. 17 (11x17 inch) plates.

Collins EW. 2004. Summary of the Balcones Fault Zone, Central Texas: a prominent zone of Tertiary normal faults marking the western margin of the
Texas coastal plain. In: Hoh A, Hunt B, editors. Tectonic history of Southern Laurentia: a look at Mesoproterozoic, Late-Paleozoic, and Cenozoic structures in central Texas. Austin Geological Society Guidebook 24, November 2004, p. 81-89.

Collins EW. 1995. Structural framework of the Edwards Aquifer, Balcones Fault Zone, Central Texas: Gulf Coast Association of Geological Societies Transactions, 45: 135-142.

Collins EW, Hovorka SD. 1997. Structure map of the San Antonio segment of the Edwards Aquifer and Balcones Fault Zone, south-central Texas: structural framework of a major limestone aquifer: Kinney, Uvalde, Median, Bexar, Comal, and Hays Counties: The University of Texas at Austin, Bureau of Economic Geology Miscellaneous Map No. 18, Scale 1:250,000, text 14 p.

DeCook KJ. 1963. Geology and ground-water resources of Hays County, Texas. US Geological Survey Water-Supply Paper 1612.

Ewing TE. 1991. Structural framework. In: Salvador A, editor. The Gulf of Mexico basin: Geological Society of America, The Geology of North America, v. J: 31-52.

Ferrill DA, Sims DW, Waiting DJ, Morris AP, Franklin NM, Shultz AL. 2004. Structural Framework of the Edwards Aquifer recharge zone in southcentral Texas. GSA Bulletin 116 (3/4): 407-418.

Grimshaw TW, Woodruff Jr CM. 1986. Structural style in an en echelon fault system, Balcones Fault Zone, Central Texas: geomorphologic and hydrologic implications. In: Abbott PL, Woodruff Jr CM, editors. The Balcones Escarpment, Central Texas. Geological Society of America, p. 71-76.

Hauwert NM, Sharp JM. 2014. Measuring autogenic recharge over a karst aquifer utilizing eddy covariance evapotranspiration. Journal of Water Resource and Protection, 6: 869-879.

Hill RT, Vaughan, TW. 1898. Geology of the Edwards Plateau and the Rio Grande Plain adjacent to Austin and San Antonio, Texas, with reference to the occurrence of underground water. US Geological Survey Annual Report Vol. 18, pt 2.

Hunt BB, Smith BA. 2010. Spring 2009 potentiometric map of the Middle Trinity Aquifer in Groundwater Management Area 9, Central Texas. Barton Springs/Edwards Aquifer Conservation District Report of Investigations 2010-0501. 26 p.

Hunt BB, Smith BA, Kromann J, Wierman DA, Mikels J. 2010. Compilation of pumping tests in Travis and Hays Counties, Central Texas. Barton Springs/ Edwards Aquifer Conservation District Data Series Report 2010-0701, 12 p. 
Hunt BB, Smith BA, Andrews A, Wierman DA, Broun AS, Gary MO. 2015. Relay ramp structures and their influence on groundwater flow in the Edwards and Trinity Aquifers, Hays and Travis Counties, Central Texas. In: Doctor DH, Land L, Stephenson JB. Proceedings of the 14th Multidisciplinary Conference on Sinkholes and the Engineering and Environmental Impacts of Karst; 2015 Oct. 5-10, 2015, Rochester, (MN): National Cave and Karst Research Institute. p. 189-199.

Hunt BB, Smith BA, Gary MO, Broun AS, Wierman DA, Watson J, Johns DA. 2017. Surface-water and groundwater interactions in the Blanco River and Onion Creek watersheds: implications for the Trinity and Edwards Aquifers of Central Texas. South Texas Geological Society Bulletin, 57 (5): 33-53.

Jones IC, Anaya R, Wade SC. 2011. Groundwater availability model: Hill Country portion of the Trinity Aquifer of Texas. Texas Water Development Board Report 377. 165 p.

Mace RE, Chowdhury AH, Anaya R, Way SC. 2000. Groundwater availability of the Trinity Aquifer, Hill Country Area, Texas-Numerical simulations through 2050. Texas Water Development Board Report 353. $119 \mathrm{p}$.

Rose PR. 1972. Edwards Group, surface and subsurface, Central Texas. The University of Texas at Austin, Bureau of Economic Geology Report of Investigations no. 74, 198 p.

Sasowsky ID. 1999. Structural effects on carbonate aquifers. In: Palmer AN, Palmer MV, Sasowsky ID, editors. Karst modeling, Karst Waters Institute Special Publication 5. p. 38-42.

Slade RM Jr, Dorsey ME, Stewart SL. 1986. Hydrology and water quality of Barton Springs and associated Edwards aquifer in the Austin area, Texas. US Geological Survey Water-Resources Investigations Report 86-4036. 117 p.

Smith BA, Hunt BB. 2010. Flow potential between stacked karst aquifers in Central Texas. In: Andreo B, Carrasco F, Duran JJ, LaMoreaux JW. Advances in Research in Karst Media, 4th International Symposium on Karst, April 26-30, 2010 Malaga, Spain, Springer, p. 43-48.

Smith BA, Hunt BB, Andrews A. 2013. Redefining the hydrostratigraphy of the Edwards and Trinity Aquifers in the Balcones Fault Zone, Hays and Travis Counties. 47th Annual Meeting of the South-Central Section Geological Society of America Abstracts with Programs Vol 45, (3) p. 91. 2013 April 4-5, Austin (TX).
Stoeser DB, Shock N, Green GN, Dumonceaux GM, Heran WD, 2005. Geologic map database of Texas. US Geological Survey Data Series 170.

Smith BA, Hunt BB, Andrews AG, Watson JA, Gary MO, Wierman DA, Broun AS. 2015. Hydrologic Influences of the Blanco River on the Trinity and Edwards Aquifers, Central Texas, USA. In: Andreo B, editor. Hydrogeological and environmental investigations in karst systems. Environmental Earth Sciences 1, Springer-Verlag Berlin Heidelberg, p. 153-161.

Stricklin F L Jr, Smith CI, FE Lozo. 1971. Stratigraphy of Lower Cretaceous Trinity deposits of Central Texas. The University of Texas at Austin, Bureau of Economic Geology Report of Investigations No. $71.63 \mathrm{p}$.

TWDB (Texas Water Development Board). 2017. Water Data Interactive [Internet]. [cited January 2017]; Available from: http://www2.twdb.texas.gov/apps/ waterdatainteractive/groundwaterdataviewer.

Watson JA, Hunt BB, Gary MO, Wierman DA, Smith BA. 2014. Potentiometric surface investigation of the Middle Trinity Aquifer in Western Hays County, Texas. Barton Springs/Edwards Aquifer Conservation District Report of Investigations 2014-1002. 21 p.

Wierman DA, Broun AS, and Hunt BB, editors. 2010. Hydrogeologic atlas of the Hill Country Trinity Aquifer, Blanco, Hays, and Travis Counties, Central Texas. Barton Springs/Edwards Aquifer Conservation District 17 (11x17 inch) plates.

Wong C, Kromann J, Hunt B, Smith B, Banner J. 2014. Investigating groundwater flow between Edwards and Trinity Aquifers in central Texas. Groundwater, 52 (4): 624-639.

Wet Rock Geological Services (WRGS). 2017. Hydrogeologic report of the Electro Purification, LLC Cow Creek well field: Hays County, Texas. Report of Findings WRGS 17-001.80 p. 
